\title{
Hormonal, follicular and endometrial dynamics in letrozole-treated versus natural cycles in patients undergoing controlled ovarian stimulation
}

\author{
Mohamed A Bedaiwy ${ }^{1,2}$, Mahmoud A Abdelaleem², Mostafa Hussein² ${ }^{2}$ Noha Mousa ${ }^{3}$, Lisa N Brunengraber ${ }^{1}$ and \\ Robert F Casper ${ }^{3^{*}}$
}

\begin{abstract}
The objective of this study was to compare letrozole-stimulated cycles to natural cycles in 208 patients undergoing intrauterine insemination (IUI) between July of 2004 and January of 2007. Group I ( $n=47)$ received cycle monitoring only (natural group), Group II ( $n=125$ ) received letrozole $2.5 \mathrm{mg} /$ day on cycle days three to seven, and Group III $(n=36)$ received letrozole $5 \mathrm{mg} /$ day on cycle days three to seven. There were no differences between the groups in endometrial thickness or $\mathrm{P}_{4}$ on the day of hCG. Estradiol levels had higher variation in the second half of the follicular phase in both letrozole-treated groups compared to the control group. Estradiol per preovulatory follicle was similar in both letrozole cycles to that observed in the natural cycles. LH was lower on the day of hCG administration in the letrozole $2.5 \mathrm{mg} /$ day group vs. the natural group. In summary, letrozole results in some minor changes in follicular, hormonal and endometrial dynamics compared to natural cycles. Increased folliculogenesis and pregnancy rates were observed in the letrozole-treated groups compared to the natural group. These findings need to be confirmed in larger, prospective studies.
\end{abstract}

\section{Background}

For over 40 years, the first-line therapy for ovulation induction (OI) has been clomiphene citrate (CC) [1]. Its inherent properties such as low price, oral route of administration and high ovulation success rate $(60-90 \%)$ make it an attractive therapy. However, the pregnancy rate is [2] disappointing. Sub-optimal pregnancy rates with CC have been attributed to peripheral anti-estrogenic effects, mainly on the endometrium and the cervical mucus[3] Gonadotropins are more effective in ovulation induction and are associated with higher pregnancy rates than CC, but are expensive and carry higher risk for ovarian hyperstimulation syndrome and multiple gestations [4].

Newer options for ovulation induction are the thirdgeneration aromatase inhibitors (AIs), the most commonly used being letrozole. Initially introduced to treat postmenopausal breast cancer, AIs are now also being

\footnotetext{
* Correspondence: casper@lunenfeld.ca

${ }^{3}$ Reproductive Sciences Division, Department of Obstetrics and Gynecology, University of Toronto, Toronto, Canada

Full list of author information is available at the end of the article
}

used for ovulation induction or enhancement. A recent meta-analysis addressing the use of letrozole in assisted conception concluded that letrozole is as effective as other methods of ovulation induction [5]. When letrozole is used in combination with gonadotropins, it leads to lower gonadotropin requirements and pregnancy rates similar to gonadotropin treatment alone [6]. In a study comparing combined therapy of letrozole $(2.5 \mathrm{mg} /$ day or $5.0 \mathrm{mg} /$ day) and recombinant FSH with recombinant FSH alone in an intrauterine insemination (IUI) program, $5 \mathrm{mg} /$ day of letrozole was more cost-effective than the $2.5 \mathrm{mg} /$ day in co-treatment with no adverse effect on pregnancy rate or outcome [7].

Aromatase inhibitors for ovulation induction are orally administered, and are relatively inexpensive with minor side effects such as very infrequent headaches and leg cramps[8]. Aromatase inhibitors increase endogenous FSH production in response to decreased estrogen biosynthesis in the ovary and extraovarian tissues, including the brain [9]. Because they do not deplete estrogen receptors like CC, normal central feedback mechanisms remain intact[10]. As the dominant follicle grows and 
estrogen levels rise, normal negative feedback occurs centrally resulting in suppression of FSH and atresia of the smaller growing follicles. Therefore, a single dominant follicle, and mono-ovulation, is the rule in most cases[11] with the clear advantage of reducing multiplegestation pregnancies.

Compared to $\mathrm{CC}$, letrozole has been associated with lower preovulatory estradiol $\left(E_{2}\right)$ levels [12], as well as thicker endometrium and a trend towards higher pregnancy rates[13]. Standard ovarian stimulation protocols often produce high preovulatory $E_{2}$ levels that could adversely affect the development of the endometrium, the follicles, and the embryo. Therefore, the lower $E_{2}$ when using AIs may lead to an improvement of implantation [14,15].

There have been several studies comparing letrozole to CC. However, there is a paucity of research comparing letrozole with natural cycles. Larger studies comparing $\mathrm{CC}$, letrozole, and natural cycles in a single study are necessary to further characterize the effect of letrozole on hormonal dynamics and pregnancy rates. Our hypothesis is that letrozole-treated cycles mimic natural cycles in hormonal and endometrial parameters. The aim of this study was to compare cycle dynamics in letrozole-treated versus natural cycles in infertile patients undergoing intrauterine insemination (IUI).

\section{Methods}

\section{Patient recruitment and counseling}

We conducted a retrospective cohort study of 208 consecutive infertile patients who were recruited to participate. Briefly, patients underwent IUI between July of 2004 and January of 2007 at the Toronto Center For Assisted Reproductive Technology, Toronto, Canada. Patients were divided into three groups. The first group ( $\mathrm{n}=47)$ received cycle monitoring only (natural cycle; group I). The 2 remaining groups received letrozole on cycle days three to seven at either $2.5 \mathrm{mg} /$ day $(\mathrm{n}=125)$ (group II) or $5 \mathrm{mg} /$ day $(\mathrm{n}=36)$ (group III). An informed consent was obtained from all participants clearly denoting the off-label use of the medication prior to treatment. Subsequently IRB approval was obtained to use their data for the purposes of this study.

Causative factors of infertility were investigated and defined as follows. Tubal patency was confirmed by sonohysterography with contrast, hysterosalpingography, and or pelvic laparoscopy. Mild male factor infertility was diagnosed according to the World Health Organization (WHO) criteria for normal semen[16]. Endometriosis was diagnosed by pelvic laparoscopy. Unexplained infertility was based on the exclusion of known factors of infertility.

\section{Cycle monitoring and insemination}

All patients were followed with serial measurements of serum estradiol $\left(\mathrm{E}_{2}\right)$, progesterone $\left(\mathrm{P}_{4}\right)$, and luteinizing hormone (LH) using a radioimmunoassay (RIA) kit. Transvaginal ultrasonography (TVS) was performed for follicular diameter tracking and measurement of endometrial thickness. We measured follicular diameter in 2 perpendicular planes and calculated the mean, while endometrial thickness was measured in the sagittal plane at the widest part of endometrial cavity. Serum samples were obtained and TVS performed on cycle days three, seven, once between days 9 and 11, the day of human chorionic gonadotropin (hCG) administration, and when a follicle achieved a diameter of $\geq 16 \mathrm{~mm}$. Serum follicle stimulating hormone (FSH) was measured on day 3 only. The results for $\mathrm{E}_{2}$ and $\mathrm{P}_{4}$ levels were reported as picomoles per liter and nanomoles per liter, respectively, and LH and FSH levels were reported in international units per liter.

An LH surge was defined as an increase in LH level greater than $100 \%$ over the mean of the preceding 2 measures. IUI was performed 36-40 hours after hCG administration if no endogenous LH surge occurred. If an endogenous LH surge was detected on the day of hCG administration, two IUIs were performed at 24 and $48 \mathrm{~h}$. Pregnancy was diagnosed by quantitative $\beta$ hCG assay two weeks after the insemination. Clinical pregnancy was confirmed by observing fetal cardiac pulsation four weeks after positive pregnancy test by TVS.

\section{Outcome parameters}

Hormonal outcome measures were $\mathrm{E}_{2}, \mathrm{P}_{4}, \mathrm{LH}$ and FSH. Non-hormonal outcomes were number and size of growing follicles, endometrial thickness, and pregnancy. All three treatment groups were compared to each other for hormonal, endometrial and follicular dynamics, while the two groups receiving letrozole were combined for comparison against the natural cycle group for pregnancy rates.

\section{Statistical analysis}

Data management was done using a preprepared Excel data spreadsheet. Outcome measures are expressed as mean \pm standard deviation from the mean (SD). Statistical significance for continuous variables was calculated using ANOVA test. Categorical variables were compared using the $\chi^{2}$ and Fisher's Exact Test. $\mathrm{P}<0.05$ was considered statistically significant. Statistical analysis was performed with SPSS (Release 14.01, SPSS Inc., Chicago, IL).

\section{Results}

\section{Patients}

The study included 208 patients who underwent a total of 300 consecutive IUI cycles. There were 71 cycles in the natural cycle group, 179 cycles in the letrozole 2.5 $\mathrm{mg} /$ day group, and 50 cycles in the letrozole $5 \mathrm{mg} /$ day 
Table 1 Study demographics

\begin{tabular}{|c|c|c|c|c|}
\hline & Group I (Natural cycle) & Group II (letrozole $2.5 \mathrm{mg}$ ) & Group III (letrozole 5 mg) & $P$ value \\
\hline Total No of patients & 47 & 125 & 36 & \\
\hline Age (Mean $\pm \underline{S D}$ ) & $34.8 \pm 5.03$ & $33.5 \pm 4.02$ & $33.88 \pm 3.45$ & NS \\
\hline Day 3 FSH (IU/L) & $6.01 \pm 1.71$ & $6.47 \pm 2.16$ & $7.49 \pm 3.76$ & $\begin{array}{l}\mid \text { | Vs ||: } 0.233 \\
\text { | Vs |||: } 0.033\end{array}$ \\
\hline Total No of cycles started & 71 & 179 & 50 & \\
\hline Completed cycle: No, [\%] & $63[88.7]$ & $142[79.3]$ & $43[86]$ & \\
\hline Total number of cycles cancelled: No, [\%] & $8[11.3]$ & 37 [20.7] & $7[14]$ & 0,06 \\
\hline No of monitoring visits (Mean $\underline{ \pm S D}$ ) & $2.08 \pm 1.02$ & $2.3 \pm 1.12$ & $2.68 \pm 1.11$ & $\begin{array}{l}\mid \text { | Vs ||: } 0.232 \\
\text { | Vs |||: } 0.003\end{array}$ \\
\hline \multicolumn{5}{|l|}{ Causes of cycle cancelling } \\
\hline Poor responder: No, [\%] & $5[62.5]$ & 9 [24.3] & $0[0]$ & NS \\
\hline Ovarian cyst: No, [\%] & $0[0]$ & $16[43.2]$ & $2[28.6]$ & NS \\
\hline Patient request: No, [\%] & $1[12.5]$ & $8[21.6]$ & $0[0]$ & NS \\
\hline Elevated FSH: No, [\%] & $0[0]$ & $2[5.4]$ & $3[42.9]$ & NS \\
\hline Others: No, [\%] & $2[25]$ & $2[5.4]$ & $2[28.6]$ & NS \\
\hline \multicolumn{5}{|l|}{ Indication for IUI } \\
\hline Male factor infertility: No, [\%] & $38 / 71[53.5]$ & $55 / 179[30.7]$ & 19/50 [38] & NS \\
\hline Unexplained infertility: No, [\%] & $33 / 71[46.5]$ & $106 / 179[59.3]$ & $30 / 50[60]$ & NS \\
\hline Endometriosis: No, [\%] & $0[0]$ & 9/179 [5] & $0[0]$ & NS \\
\hline Others No, [\%] & $1 / 71[1.4]$ & $9 / 179[5]$ & $1[2]$ & NS \\
\hline
\end{tabular}

group (table 1). Male factor and unexplained infertility were the most common indications for IUI. Other identified causes of infertility included endometriosis, and polycystic ovarian syndrome. The most frequent cause of cycle cancellation differed among the patient groups. The most common cause of cancellation in the natural cycle group was anovulation, while in the letrozole 2.5 $\mathrm{mg} /$ day group, the main cause was presence of ovarian cysts on cycle day 3 before the start of stimulation. The most common cause of cancellation in the letrozole 5 $\mathrm{mg} /$ day group was an elevated serum FSH on cycle day 3 before the start of stimulation.

\section{Hormonal dynamics}

Values for $\mathrm{E}_{2}, \mathrm{P}_{4}$ and $\mathrm{LH}$ are shown in table 2. The letrozole $5 \mathrm{mg}$ /day group had significantly lower $\mathrm{E}_{2}$ on day seven, but significantly higher $\mathrm{E}_{2}$ on the day of hCG administration when compared to the natural group ( $\mathrm{P}=$ 0.025 and 0.041 , respectively). However, the $\mathrm{E}_{2}$ per preovulatory follicle was similar in all three groups on the day of hCG. On days 9 to 11 and the day of hCG administration, $E_{2}$ had a larger variability, as evidenced by larger standard deviations, in the letrozole groups compared to the natural group (Table 2). LH was significantly lower on the day of hCG administration in the letrozole $2.5 \mathrm{mg} /$ day

Table 2 Hormonal dynamics: follicular phase levels of serum estradiol, progesterone, and LH

\begin{tabular}{|c|c|c|c|c|c|c|c|c|c|}
\hline & \multicolumn{3}{|c|}{ Estradiol (pmol/mL) } & \multicolumn{3}{|c|}{ Progesterone (pmol/mL) } & \multicolumn{3}{|c|}{ LH (IU/L) } \\
\hline & $\begin{array}{l}\text { Group I } \\
\text { (Natural } \\
\text { cycle) }\end{array}$ & $\begin{array}{c}\text { Group II } \\
\text { letrozole } 2.5 \\
\text { mg }\end{array}$ & $\begin{array}{c}\text { Group III } \\
\text { (letrozole } 5 \\
\mathrm{mg})\end{array}$ & $\begin{array}{l}\text { Group I } \\
\text { (Natural } \\
\text { cycle) }\end{array}$ & $\begin{array}{c}\text { Group II } \\
\text { (letrozole } 2.5 \\
\text { mg }\end{array}$ & $\begin{array}{c}\text { Group III } \\
\text { (letrozole } 5 \\
\mathrm{mg})\end{array}$ & $\begin{array}{l}\text { Group I } \\
\text { (Natural } \\
\text { cycle) }\end{array}$ & $\begin{array}{c}\text { Group II } \\
\text { (letrozole } 2.5 \\
\text { mg }\end{array}$ & $\begin{array}{c}\text { Group III } \\
\text { (letrozole } 5 \\
\text { mg) }\end{array}$ \\
\hline D3 & $\begin{array}{c}139.8 \pm \\
66.36\end{array}$ & $\begin{array}{c}154.22 \pm \\
131.31\end{array}$ & $\begin{array}{c}126.71 \pm \\
46.75\end{array}$ & $2.35 \pm 0.84$ & $2.57 \pm .90$ & $2.55 \pm .89$ & $5.18 \pm 2.25$ & $5.22 \pm 3.41$ & $5.28 \pm 2.71$ \\
\hline D7 & $\begin{array}{c}257.75 \pm \\
187.8\end{array}$ & $\begin{array}{c}196.60 \pm \\
127.07\end{array}$ & $\begin{array}{c}147.63 \pm \\
69.74\end{array}$ & $2.08 \pm 0.40$ & $2.37 \pm 0.87$ & $2.80 \pm 0.82$ & $5.1 \pm 1.34$ & $6.71 \pm 4.23$ & $8.28 \pm 4.07$ \\
\hline D 9-11 & $\begin{array}{c}380.48 \pm \\
238.78\end{array}$ & $\begin{array}{c}810.05 \pm \\
178.26\end{array}$ & $\begin{array}{c}562.53 \pm \\
137.51\end{array}$ & $2.35 \pm 0.85$ & $2.2 \pm 0.79$ & $2.67 \pm 0.47$ & $5.89 \pm 2.96$ & $5.76 \pm 3.30$ & $6.65 \pm 2.95$ \\
\hline $\mathrm{D} h C G$ & $\begin{array}{c}911.48 \pm \\
941.96\end{array}$ & $\begin{array}{c}1275.41 \pm \\
927.66\end{array}$ & $\begin{array}{c}1066.16 \pm \\
1876.37\end{array}$ & $2.46 \pm 1.32$ & $2.40 \pm 0.89$ & $2.75 \pm 0.75$ & $\begin{array}{c}17.39 \pm \\
16.09\end{array}$ & $8.92 \pm 9.86$ & $10.50 \pm 13.81$ \\
\hline $\begin{array}{l}\text { E2/follicle } \\
\geq 16 \mathrm{~mm}\end{array}$ & $\begin{array}{c}593.12 \pm \\
577.4\end{array}$ & $\begin{array}{c}584.41 \pm \\
1147.84\end{array}$ & $\begin{array}{c}389.8 \pm \\
849.79\end{array}$ & & & & & & \\
\hline
\end{tabular}

P value: 0.025: day7 for serum Estradiol between group I and III.

P value: 0.041 day of hCG For serum Estradiol between group I and III.

P value: $0.000 \mathrm{LH}$ at day of HCG group I vs II 
Table 3 Follicular dynamics in study groups

\begin{tabular}{|c|c|c|c|c|}
\hline & Group I & Group II & Group III & $P$ value \\
\hline \multirow[t]{2}{*}{ Day 3 diameter of follicles in $\mathrm{cm}$} & $0.56 \pm 1.02$ & $0.79 \pm 1.12$ & $0.53 \pm 0.86$ & | vs |||: 0.9 \\
\hline & & & & | vsll: 0.26 \\
\hline \multirow[t]{2}{*}{ Number of $D 7-8$ follicles $\geq 10 \mathrm{~mm}$} & $0.80 \pm 0.63$ & $2.52 \pm 1.37$ & $2.23 \pm 1.48$ & I vs |||: 0.000 \\
\hline & & & & I vsll: 0.000 \\
\hline \multirow[t]{2}{*}{ Number of D 9-11follicles more than $12 \mathrm{~mm}$} & $1.13 \pm 0.73$ & $2.09 \pm 1.00$ & $2.29 \pm 1.35$ & I vs III: 0.005 \\
\hline & & & & | vsll: 0.000 \\
\hline \multirow[t]{2}{*}{ Number of mature follicles ( $\geq 15 \mathrm{~mm}$ ) at the Day of hCG } & $1.20 \pm 0.48$ & $1.84 \pm 0.92$ & $2.12 \pm 0.99$ & I vs III: 0.000 \\
\hline & & & & | vsll: 0.000 \\
\hline
\end{tabular}

group compared to the natural group $(\mathrm{p}=0.000)$. $\mathrm{P}_{4}$ showed no differences between any treatment groups.

\section{Follicular dynamics}

There were no statistically significant differences in follicular diameter between the three groups until cycle day seven (table 3).Compared to the natural group, both the letrozole $2.5 \mathrm{mg} /$ day and $5 \mathrm{mg} /$ day groups had significantly more follicles $\geq 10 \mathrm{~mm}$ on day 7 ( $\mathrm{p}=0.0001$ and 0.0001 , respectively), more follicles $\geq 12 \mathrm{~mm}$ on days 911 ( $\mathrm{p}=0.0001$ and 0.005 ), and more follicles $\geq 15 \mathrm{~mm}$ on the day of hCG administration ( $\mathrm{p}=0.0001$ and $0.0001)$.

\section{Endometrial dynamics}

When comparing endometrial thickness, neither letrozole group differed significantly from the natural group on any day (table 4).

\section{Pregnancy rate}

Three out of 63 natural cycles (4.8\%) and 22 out of 185 letrozole cycles (12\%) resulted in pregnancy (table 5). This difference was statistically significant $(\mathrm{p}==0.02)$. Although only a small number of cycles were repeated as part of this study, the cumulative pregnancy rate was $13.7 \%$ in the letrozole groups, significantly higher than the natural group rate of $6.4 \%(\mathrm{p}=0.01)$. There were 3 twin pregnancies in the 2 letrozole groups and none in the natural cycle group.

\section{Discussion}

Endometrial sparing, increased folliculogenesis, and an increase in pregnancy rate were observed in our

Table 4 Endometrial thickness $(\mathrm{cm})$ in study groups

\begin{tabular}{lccc}
\hline & Group I & Group II & Group III \\
\hline Cycle day 3 & $0.14 \pm 0.26$ & $0.10 \pm 0.23$ & $0.15 \pm 0.24$ \\
Cycle day 7 & $0.55 \pm 0.26$ & $0.56 \pm 0.19$ & $0.50 \pm 0.19$ \\
Cycle day 9-11 & $0.65 \pm 0.18$ & $0.77 \pm 0.96$ & $0.62 \pm 0.16$ \\
Day of hCG injection & $0.86 \pm 0.16$ & $0.82 \pm 0.14$ & $0.86 \pm 0.23$ \\
\hline
\end{tabular}

$P$ value non-significant when comparing group I to either group II or III. letrozole-treated patients as compared to naturallycycling patients. The endometrial-sparing effect of letrozole is well-demonstrated in this study by the lack of significant difference in endometrial thickness compared to the natural cycle group, and also has been confirmed by previous studies $[17,18]$. In addition, our ovulation monitoring findings agree with a previous study showing multifollicular development and better pregnancy outcomes with the use of letrozole $5 \mathrm{mg} /$ day $[14,17]$. Our finding that serial serum progesterone levels were comparable between the three groups agrees with a previous study [18], and suggests that letrozole does not have a premature luteinizing effect on the developing follicle. Table 6 summarizes the results of some trials using letrozole as an ovulation inducing agent in different clinical scenaria with different results and conclusions.

Although basal LH levels were comparable among the 3 groups, there was a trend towards higher $\mathrm{LH}$ (although non-significant) on day 7 in the letrozole groups. This rise might be due to the release of the anterior pituitary from the negative feedback of $E_{2}$. Three important observations deserve mentioning. First, the increase in LH is still well-below the levels for definition of premature LH surge. Second, after discontinuation of letrozole (days 9-11), serum LH returned to levels similar to the non-stimulated group reflecting the short half life of the letrozole. Thirdly, a natural LH surge was observed more frequently in non-stimulated cycles than in the letrozole stimulated cycles. This finding is likely artifactual since we suggest hCG

Table 5 Pregnancy rate in study groups

\begin{tabular}{lccc}
\hline & $\begin{array}{c}\text { Group I } \\
\text { Number (\%) }\end{array}$ & $\begin{array}{c}\text { Combined groups II, III } \\
\text { Number (\%) }\end{array}$ & $\begin{array}{c}\text { P } \\
\text { value }\end{array}$ \\
\hline $\begin{array}{l}\text { Pregnancy rate/cycle } \\
\text { started }\end{array}$ & $3 / 71(4.2)$ & $22 / 229(9.61)$ & $\mathbf{0 . 0 2}$ \\
$\begin{array}{l}\text { Pregnancy rate/cycle } \\
\text { completed }\end{array}$ & $3 / 63(4.8)$ & $22 / 185(11.89)$ & $\mathbf{0 . 0 2}$ \\
$\begin{array}{l}\text { Cumulative } \\
\text { pregnancy rate }\end{array}$ & $3 / 47(6.4)$ & $22 / 161(13.7)$ & $\mathbf{0 . 0 1}$ \\
$\begin{array}{l}\text { Twin pregnancy } \\
\text { Miscarriage (No) }\end{array}$ & $0 / 3(0)$ & $3 / 22(13.6)$ & $\mathbf{0 . 0 1}$ \\
\hline
\end{tabular}


Table 6 Summary of randomized trials assessing the efficacy of letrozole

\begin{tabular}{|c|c|c|c|}
\hline $\begin{array}{l}\text { Study } \\
\text { (reference } \\
\text { number) }\end{array}$ & Intervention & Cohort of patients & Conclusion \\
\hline [20] & Letrozole (2.5 mg) Vs CC & $\begin{array}{l}\text { Infertile women undergoing } \\
\text { Superovulation and IUI. }\end{array}$ & Similar endometrial thickness and pregnancy rates. \\
\hline [21] & $\begin{array}{l}\text { letrozole Vs CC as adjuvants } \\
\text { to rFSH } 41 \text { patients }\end{array}$ & $\begin{array}{l}\text { Superovulation before IUI in } \\
\text { unexplained infertility }\end{array}$ & Better endometrial thickness with letrozole. Similar pregnancy rate \\
\hline [22] & Letrozole Vs CC 74 patients & Polycystic ovary syndrome & Similar endometrial thickness and pregnancy rate \\
\hline [23] & Letrozole (2.5 mg) Vs CC & Polycystic ovary syndrome & Better endometrial thickness and pregnancy rate with letrozole. \\
\hline [24] & Letrozole Vs CC & Polycystic ovary syndrome & $\begin{array}{l}\text { No advantage to the use of letrozole over CC as a first-line treatment } \\
\text { for induction of ovulation in women with PCOS }\end{array}$ \\
\hline$[25,26]$ & Letrozole Vs CC & $\begin{array}{l}\text { Superovulation before IUI in } \\
\text { unexplained infertility }\end{array}$ & $\begin{array}{l}\text { No superiority between letrozole and CC for inducing ovulation in } \\
\text { women with unexplained infertility before IUI. }\end{array}$ \\
\hline [27] & $\begin{array}{l}\text { Letrozole Vs CC- } \\
\text { gonadotropin }\end{array}$ & $\begin{array}{l}\text { Superovulation before IUI in } \\
\text { unexplained infertility }\end{array}$ & Letrozole is a good alternative to CC-gonadotropin. \\
\hline [28] & $\begin{array}{l}\text { Letrozole }(2.5 \mathrm{mg}) \text { Vs CC } 22 \\
\text { patients }\end{array}$ & $\begin{array}{l}\text { superovulation in women with } \\
\text { normal ovulation }\end{array}$ & $\begin{array}{l}\text { CC is superior to } 2.5 \mathrm{mg} \text { letrozole for superovulation induction in } \\
\text { women with normal ovulation. }\end{array}$ \\
\hline [29] & $\begin{array}{l}\text { Letrozole }(7.5 \mathrm{mg}) \text { Vs CC } 46 \\
\text { patients }\end{array}$ & Polycystic ovary syndrome & $\begin{array}{l}\text { Letrozole has better ovulation and PR in comparison to CC in patients } \\
\text { with PCOS }\end{array}$ \\
\hline
\end{tabular}

administration to all women undergoing IUI so that timing of insemination can be optimized. The women undergoing natural cycle monitoring usually requested everything to be natural including no hCG trigger so the difference between the groups is unlikely to be related to the letrozole. Spontaneous LH surges do occur with letrozole for ovulation induction.

This study has some limitations, the most important of which include that it is retrospective, non-powered, non-randomized and not blinded. These issues are inherent in retrospective studies. However, we believe the results are of interest since there are few studies comparing natural cycles to letrozole-stimulated cycles. The main distinguishing features of letrozole as an ovulation inducing agent is its endometrial sparing effect and the early cycle multi-follicular development that may have translated into a better pregnancy rate in the present study. In addition, a recent study demonstrated that letrozole improves blood flow compared to CC and this observation may also be associated with improved pregnancy rates [19]. A well-designed and powered randomized clinical trial will be needed to confirm this result.

The authors declare that they have no competing interests.

\section{Author details \\ 'Department of Obstetrics and Gynecology, University Hospitals Case Medical Center, Case Western Reserve University School of Medicine, Cleveland, Ohio, USA. ${ }^{2}$ Assiut University, Assiut, Egypt. ${ }^{3}$ Reproductive Sciences Division, Department of Obstetrics and Gynecology, University of Toronto, Toronto, Canada.}

\section{Authors' contributions}

MAB collected and analyzed the data and drafted the manuscript. MAA Collected the data and drafting the manuscript. $\mathrm{MH}$ participated in the data collection. NM participated in the design of the study and performed the statistical analysis. LNB: participated in the data collection and helped to draft the manuscript. RC Conceived the idea of the study, and participated in its design and coordination and helped to draft the manuscript. All authors read and approved the final manuscript.

\section{Competing interests}

The authors declare that they have no competing interests.

Received: 19 August 2010 Accepted: 21 June 2011

Published: 21 June 2011

\section{References}

1. Casper RF: Aromatase inhibitors in ovarian stimulation. J Steroid Biochem Mol Biol 2007, 106:71-75.

2. Neveu NGL, St.-Michel P, Lavoie HB: Comparison of clomiphene citrate, metformin, or the combination of both for first-line ovulation induction and achievement of pregnancy in 154 women with polycystic ovary syndrome. Fertil Steril 2007, 87:113-120.

3. Gorlitsky GAKN, Speroff L: Ovulation and pregnancy rates with clomiphene citrate. Obstet Gynecol 1978, 51:265-269.

4. Guzick DSCS, Coutifaris C, Overstreet JW, Factor-Litvak P, Steinkampf MP Hill JA, Mastroianni L, Buster JE, Nakajima ST, Vogel DL, Canfield RE: Efficacy of superovulation and intrauterine insemination in the treatment of infertility. National Cooperative Reproductive Medicine Network. N Engl J Med 1999, 340:177-183.

5. Requena A, Herrero J, Landeras J, Navarro E, Neyro JL, Salvador C, Tur R, Callejo J, Checa MA, Farre M, Espinós JJ, Fábregues F, Graña-Barcia M: Use of letrozole in assisted reproduction: a systematic review and metaanalysis. Hum Reprod Update 2008, 14:571-582.

6. Holzer H, Casper R, Tulandi T: A new era in ovulation induction. Fertil Steril 2006, 85:277-284.

7. Noriega-Portella L, Noriega-Hoces L, Delgado A, Rubio J, GonzalesCastaneda C, Gonzales GF: Effect of letrozole at $2.5 \mathrm{mg}$ or $5.0 \mathrm{mg} /$ day on ovarian stimulation with gonadotropins in women undergoing intrauterine insemination. Fertil Steril 2008, 90:1818-1825.

8. Hamilton A, Piccart M: The third-generation non-steroidal aromatase inhibitors: a review of their clinical benefits in the second-line hormonal treatment of advanced breast cancer. Ann Oncol 1999, 10:377-384.

9. Naftolin : Brain aromatization of androgens. J Reprod Med 1994, 39:257-261.

10. Robert F, Casper MFMM: Aromatase Inhibitors for Ovulation Induction. $J$ Clin Endocrinol Metab 2006, 91:760-771.

11. Casper RF: Letrozole versus clomiphene citrate: which is better for ovulation induction? Fertil Steril 2009, 92:858-9. 
12. Bayar U, Basaran M, Kiran S, Coskun A, Gezer S: Use of an aromatase inhibitor in patients with polycystic ovary syndrome: a prospective randomized trial. Fertil Steril 2006, 86:1447-1451.

13. Serdar B: Ovulation induction in women with infertility: a new indication for aromatase inhibitors. Fertil Steril 2003, 80(6):1338.

14. Simón CCF, Valbuena D, Remohí J, Pellicer A: Clinical evidence for a detrimental effect on uterine receptivity of high serum oestradiol concentrations in high and normal responder patients. Hum Reprod 1995, 10:2432-2437.

15. Simon C, Cano F, Valbuena D, Remohi J, Pellicer A: Clinical evidence for a detrimental effect on uterine receptivity of high serum oestradiol concentrations in high and normal responder patients. Hum Reprod 1995, 10:2432-2437.

16. Organization WH: WHO laboratory manual for the examination of human semen and sperm-cervical mucus interaction. 4 edition. Cambridge: Cambridge University Press; 1999

17. Bedaiwy MA, Mousa NA, Casper RF: Aromatase inhibitors prevent the estrogen rise associated with the flare effect of gonadotropins in patients treated with GnRH agonists. Fertil Steril 2009, 91:1574-1577.

18. Bedaiwy MA, Shokry M, Mousa N, Claessens A, Esfandiari N, Gotleib L, Casper R: Letrozole co-treatment in infertile women 40 years old and older receiving controlled ovarian stimulation and intrauterine insemination. Fertil Steril 2009, 91:2501-2507.

19. Baruah J, Roy KK, Rahman SM, Kumar S, Sharma JB, Karmakar D: Endometrial effects of letrozole and clomiphene citrate in women with polycystic ovary syndrome using spiral artery Doppler. Arch Gynecol Obstet 2009, 279:311-314

20. Al-Fozan H, Al-Khadouri M, Tan SL, Tulandi T: A randomized trial of letrozole versus clomiphene citrate in women undergoing superovulation. Fertil Steril 2004, 82:1561-1563.

21. Barroso G, Menocal G, Felix H, Rojas-Ruiz JC, Arslan M, Oehninger S: Comparison of the efficacy of the aromatase inhibitor letrozole and clomiphene citrate as adjuvants to recombinant follicle-stimulating hormone in controlled ovarian hyperstimulation: a prospective, randomized, blinded clinical trial. Fertil Steril 2006, 86:1428-1431.

22. Bayar U, Tanriverdi HA, Barut A, Ayoglu F, Ozcan O, Kaya E: Letrozole vs. clomiphene citrate in patients with ovulatory infertility. Fertil Steril 2006, 85:1045-1048.

23. Atay V, Cam C, Muhcu M, Cam M, Karateke A: Comparison of letrozole and clomiphene citrate in women with polycystic ovaries undergoing ovarian stimulation. J Int Med Res 2006, 34:73-76.

24. Badawy A, Abdel Aal I, Abulatta M: Clomiphene citrate or letrozole for ovulation induction in women with polycystic ovarian syndrome: a prospective randomized trial. Fertil Steril 2009, 92:849-52.

25. Badawy A, Shokeir T, Allam AF, Abdelhady H: Pregnancy outcome after ovulation induction with aromatase inhibitors or clomiphene citrate in unexplained infertility. Acta Obstet Gynecol Scand 2009, 88:187-191.

26. Badawy A, Elnashar A, Totongy M: Clomiphene citrate or aromatase inhibitors for superovulation in women with unexplained infertility undergoing intrauterine insemination: a prospective randomized trial. Fertil Steril 2009, 92:1355-1359.

27. Sh Tehrani Nejad E, Abediasl Z, Rashidi BH, Azimi Nekoo E, Shariat M, Amirchaghmaghi E: Comparison of the efficacy of the aromatase inhibitor letrozole and clomiphen citrate gonadotropins in controlled ovarian hyperstimulation: a prospective, simply randomized, clinical trial. J Assist Reprod Genet 2008, 25:187-190.

28. Topipat C, Choktanasiri W, Jultanmas R, Weerakiet S, Wongkularb A, Rojanasakul A: A comparison of the effects of clomiphene citrate and the aromatase inhibitor letrozole on superovulation in Asian women with normal ovulatory cycles. Gynecol Endocrinol 2008, 24:145-150.

29. Begum MR, Ferdous J, Begum A, Quadir E: Comparison of efficacy of aromatase inhibitor and clomiphene citrate in induction of ovulation in polycystic ovarian syndrome. Fertil Steril 2009, 92:853-7.

doi:10.1186/1477-7827-9-83

Cite this article as: Bedaiwy et al:: Hormonal, follicular and endometrial dynamics in letrozole-treated versus natural cycles in patients undergoing controlled ovarian stimulation. Reproductive Biology and

Endocrinology 2011 9:83.

\section{Submit your next manuscript to BioMed Central and take full advantage of:}

- Convenient online submission

- Thorough peer review

- No space constraints or color figure charges

- Immediate publication on acceptance

- Inclusion in PubMed, CAS, Scopus and Google Scholar

- Research which is freely available for redistribution

Submit your manuscript at www.biomedcentral.com/submit
Biomed Central 